Jurnal Informatika dan Rekayasa Perangkat Lunak (JATIKA)
Vol. 1, No. 2, December 2020, 174-182
ISSN 2723-3367
available online at:http:///im.teknokrat.ac.id/index.php/informatika

\title{
SISTEM INFORMASI INVENTORY GUDANG DALAM KETERSEDIAAN STOK BARANG MENGGUNAKAN METODE BUFFER STOK
}

\author{
Ade Ferry Qadafi ${ }^{1}$, Agung Deni Wahyudi ${ }^{2}$ \\ Universitas Teknokrat Indonesia ${ }^{\mathbf{1 , 2}}$
}

adef.qadafi@gmail.com¹, agungdeniwahyudi@teknokrat.ac.id ${ }^{2}$

Received: (12 Desember 2020)Accepted: (30 Desember 2020) Published: (31 Desember 2020)

\begin{abstract}
Rika 86 is a company engaged in convection, founded in 1986, and only has one tailor and one person for screen printing. Rika 86 has activities in the sale, purchase and return of goods. However, until now there has been no system that manages data on the stock of goods, so companies want to have a system that can be used to find out the inventory, so they can easily find out the quantity and place of storing inventory. Currently, inventory data is still stored in several books, where only the unit price of the inventory and the amount of stock is recorded without any more detailed information on the inventory book. Inventory purchase notes often lose because their storage is still in the form of an archive which causes no record of order data. With this problem, the service process to customers is hampered, the product manufacturing process is hampered and if the inventory is out of stock but is not in stock again it will take time to order the goods back. With this inventory information system using the waterfall system development method, and using PIECES analysis and application systems designed using the UML (Unified Modeling Language) system design method with usecase diagrams, class diagrams and activity diagrams. The coding system or programming language used is PHP with the MYSQL database. The results obtained from this research are that the process of stock inventory using the Buffer Stock method can help the Rika 86 Lampung convection to find out the amount of goods or materials in stock and to know the amount of inventory that must be ordered based on the calculation of Buffer Stock.
\end{abstract}

Keywords: System, Inventory, Goods, Buffer Stock, Web

\begin{abstract}
Abstrak
Rika 86 merupakan sebuah perusahaan yang bergerak dibidang konveksi, Didirikan pada tahun 1986, dan hanya memiliki satu orang penjahit dan satu orang untuk sablon. Rika 86 memiliki kegiatan penjualan, pembelian dan retur barang. Namun, sampai saat ini belum ada sistem yang mengelola data tentang stok persediaan barang untuk itu perusahaan ingin memiliki sebuah sistem yang dapat digunakan untuk mengetahui persediaan barang, agar dapat dengan mudah mengetahui jumlah dan tempat penyimpanan persediaan barang. Saat ini data persediaan barang masih disimpan dalam beberapa buku, dimana yang di catat hanya harga satuan persediaan barang dan jumlah stok tanpa adanya keterangan lebih terperinci pada buku stok persediaan barang. Nota pembelian persediaan barang sering terjadi kehilangan karena penyimpanannya masih berupa arsip yang menyebabkan tidak adanya rekam data order. Dengan masalah tersebut proses pelayanan kepada pelanggan menjadi terhambat, proses pembuatan produk menjadi terhambat dan jika persediaan barang yang sudah habis tetapi tidak di stok kembali maka akan memakan waktu untuk mengorder barang kembali. Dengan adanya sistem informasi persediaan ini serta sistem aplikasi yang dirancang dengan mengunakan metode perancangan sistem UML (Unified Modeling Language). Pengkodean sistem atau bahasa pemrograman yang digunakan yaitu PHP dengan database MySQL, serta hasil pengujian bahwa kualitas perangkat lunak yang dihasilkan memiliki tingkat yang Sangat Layak.
\end{abstract}

Kata Kunci: Sistem, Inventory, Barang, Buffer Stock, Web 
To cite this article:

Ade Ferry Qadafi, Agung Deni Wahyudi. (2020). Sistem Informasi Inventory Gudang Dalam Ketersediaan Stok Barang Menggunakan Metode Buffer Stok. Jurnal Informatika dan Rekayasa Perangkat Lunak, Vol(1) No(2), 174-182.

\section{PENDAHULUAN}

Sistem persediaan barang adalah suatu sistem untuk mengelola persediaan barang di gudang. Sistem persediaan barang kini sudah banyak digunakan oleh perusahaan-perusahaan berkembang, terutama dalam hal pengolahan data barang. persediaan barang merupakan komponen utama yang sangat penting dalam suatu perusahaan, karena persediaan akan dijual secara terus menerus untuk kelancaran bisnis perusahaan, selain itu persediaan barang merupakan aset harta yang cukup besar jika dibandingkan dengan harta lancar lainnya. Pengendalian besarnya nilai persediaan barang bukanlah hal yang mudah bagi perusahaan, dari mulai melakukan pencatatan harga pembelian barang, menentukan harga sampai dengan penyajian persediaan barang tersebut kedalam laporan keuangan (Maulida, Hamidy and Wahyudi, 2020). Untuk memudahkan pengendalian persediaan barang, maka dibutuhkan sebuah sistem yang bertujuan untuk mempermudah proses pengendalian persediaan barang yang diharapkan dapatmembantu masalah-masalah yang ada pada perusahaan (Nawang, Kurniawati and Duta, 2017).

Rika 86 merupakan sebuah perusahaan yang bergerak dibidang konveksi, Didirikan pada tahun 1986, dan hanya memiliki satu orang penjahit dan satu orang untuk sablon. Saat ini memiliki 15 karyawan dan 2 workshop di Bandar Lampung dan Pringsewu. Produk yang dihasilkan antara lain adalah seragam sekolah, baju olahraga, jaket, jas almamater, PDH, toga dan lain-lain. Rika 86 memiliki kegiatan penjualan, pembelian dan retur barang. Namun, sampai saat ini belum ada sistem yang mengelola data tentang stok persediaan barang untuk itu perusahaan ingin memiliki sebuah sistem yang dapat digunakan untuk mengetahui persediaan barang, agar dapat dengan mudah mengetahui jumlah dan tempat penyimpanan persediaan barang.

Data persediaan barang masih disimpan dalam beberapa buku, dimana yang di catat hanya harga satuan persediaan barang dan jumlah stok tanpa adanya keterangan lebih terperinci pada buku stok persediaan barang. Nota pembelian persediaan barang sering terjadi kehilangan karena penyimpanannya masih berupa arsip yang menyebabkan tidak adanya rekam data order. Dengan masalah tersebut proses pelayanan kepada pelanggan menjadi terhambat, proses pembuatan produk menjadi terhambat dan jika persediaan barang yang sudah habis tetapi tidak di stok kembali maka akan memakan waktu untuk mengorder barang kembali.

Dengan adanya sistem informasi persediaan mampu mengatasi masalah persediaan barang yang ada pada Rika 86 Lampung dan penggunaan metode buffer stock dalam perhitungan persediaan mampu menggambarkan tingkat stok ekstra yang dipertahankan untuk mengurangi resiko stock outs (kekurangan bahan baku) karena ketidakpastian pasokan dan permintaan. Adapun keunggulan dari metode buffer stock yaitu mengurangi resiko keterlambatan pengiriman barang yang berdampak pada persediaan bahan baku yang tidak tersedia saat dipesan oleh pelanggan, mengurangi resiko kenaikan harga yang berdampak pada harga penjualan bahan baku yang akan dijual kepada pelanggan menjadi lebih mahal, dan dapat mengantisipasi permintaan pemesanan dengan jumlah yang banyak. Maka diusulkan sebuah Sistem Informasi Inventory Gudang Dalam Ketersediaan Stok Barang Menggunakan Metode Buffer Stok Berbasis Web (Megawaty et al., 2020).

\section{TELAAH PUSTAKA \\ Parameter Persediaan}

Parameter-parameter masalah persediaan mempunyai dua karakteristik utama, yaitu tingkat permintaan dan periode kedatangan pesanan. Model-model persediaan dibedakan menjadi dua model yaitu model Deterministik dan model Probabilistik. Kelompok model Deterministik ditandai oleh karakteristik tingkat permintaan dan periode kedatangan pesanan yang bisa diketahui sebelumnya secara pasti. Sebaliknya, jika salah satu atau kedua parameter itu tidak dapat diketahui secara pasti sebelumnya, sehingga harus didekati dengan distribusi probabilitas, maka hal itu termasuk kelompok model Probabilistik (Prawirosentono, 2015).

Tujuan yang hendak dicapai dalam suatu penyelesaian masalah persediaan adalah akan meminimumkan biaya total persediaan. Biaya-biaya yang digunakan adalah :

1. Biaya Pesan (Ordering Cost) yaitu Biaya pesan timbul pada saat terjadi proses pemesanan suatu barang. Biaya-biaya pembuatan surat, telepon, fax dan biaya-biaya overhand lain yang secara proporsional timbul karena proses pembuatan sebuah pesanan barang adalah contoh biaya pesan. 
2. Biaya Simpan (Carrying Cost) yaitu Biaya simpan timbul pada saat terjadi proses penyimpanan suatu barang. Biaya-biaya sewa gedung, premi asuransi, biaya keamanan dan biaya-biaya overhand lain yang timbul karena proses penyimpanan suatu barang, maka dikenakan biaya simpanan.

3. Biaya Kehabisan Persediaan (Stockout Cost) yaitu Biaya kehabisan pesanan timbul pada saat persediaan habis atau tidak tersedia. Termasuk dalam kategori biaya ini adalah kerugian karena mesin berhenti atau karyawan tidak bekerja dan peluang yang hilang untuk memperoleh keuntungan.

4. Biaya Pembeli (Purchase Cost) yaitu Biaya pembelian yang timbul pada saat pembelian suatu barang.

\section{Website}

Website adalah suatu media publikasi elektronik yang terdiri dari halaman-halaman web (web page) yang terhubung satu dengan yang lain menggunakan link yang dilekatkan pada suatu teks atau image (Setiawansyah, Sulistiani and Darwis, 2020). Website dibangun dengan menggunakan bahasa Hypertext Markup Language (HTML) dan memanfaatkan protokol komunikasi Hypertext Transfer Protocol (HTTP) yang terletak pada application layer pada referensi layer OSI. Halaman website diakses menggunakan aplikasi yang disebut internet browser (Wulandari and Sulistiani, 2020).

\section{Unified Modeling Language (UML)}

Unified Modeling Language (UML) adalah sebuah bahasa untuk menentukan, visualisasi, kontruksi, dan mendokumentasikan artifact (bagian dari informasi yang digunakan atau dihasilkan dalam suatu proses pembuatan perangkat lunak). UML merupakan notasi yang lengkap untuk membuat visualisasi model suatu sistem. Sistem berisi informasi dan fungsi, namun secara normal digunakan untuk pemodelan sistem komputer. UML tidak hanya digunakan dalam proses pemodelan perangkat lunak, namun hampir dalam semua bidang yang membutuhkan pemodelan. (Rosa, 2016).

\section{METODE PENELITIAN}

\section{Kerangka Penelitian}

Kerangka penelitian adalah suatu rancangan alur sebuah penelitian yang terstruktur disampaikan melalui gambar yang berurutan (Sulistiani et al., 2020). Berikut gambar kerangka penelitian yang diajukan peneliti dapat dilihat pada gambar 1. dibawah ini 


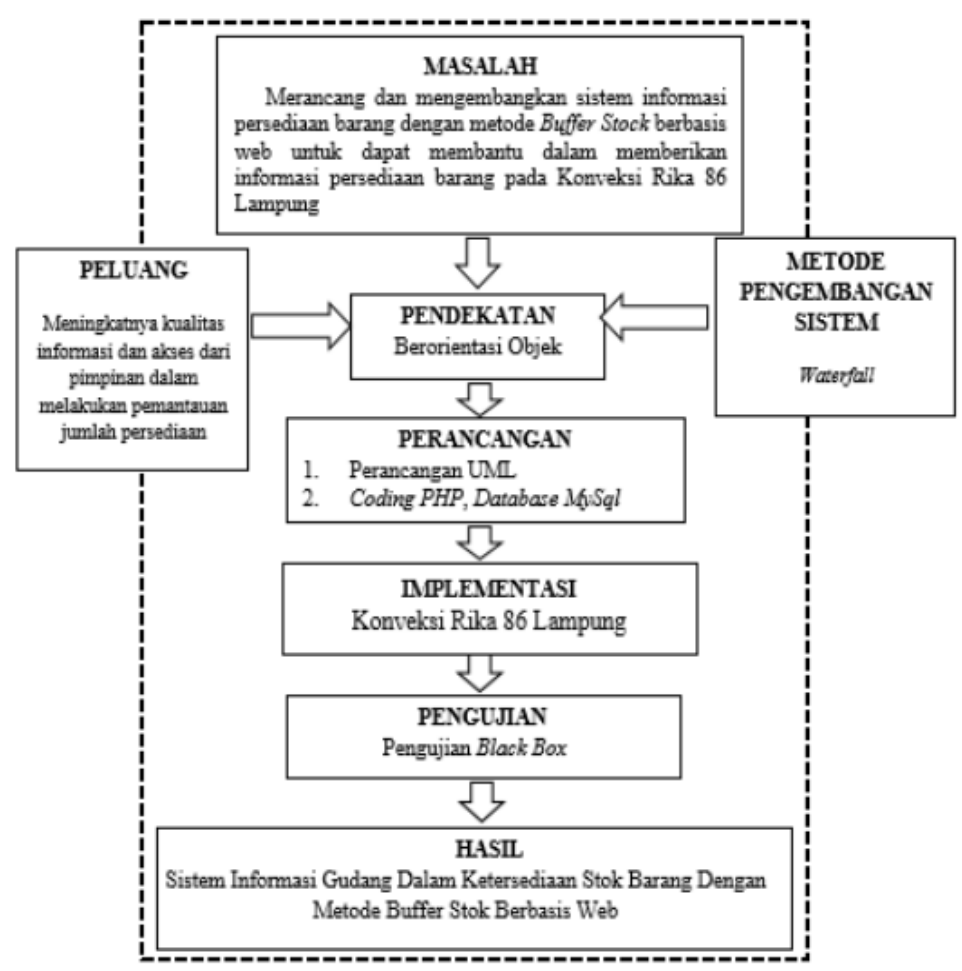

Gambar 1 Kerangka Penelitian

\section{Teknik Pengumpulan Data}

Tahapan ini memperoleh data sebagai bahan penelitian dengan menggunakan beberapa metode dalam melakukan penelitian yaitu sebagai berikut:

1. Pengamatan : Metode ini dilakukan dengan cara pengumpulan data melalui proses pengamatan secara langsung kepada Konveksi Rika 86.

2. Wawancara : Metode ini dilakukan dengan cara mengajukan pertanyaan secara langsung dengan pimpinan Konveksi Rika 86.

3. Tinjauan Pustaka : Pada tahap ini akan diadakan tinjauan pustaka yang bertujuan untuk membandingkan dengan penelitian terdahulu dan mengumpulkan data-data yang dibutuhkan dan berkaitan dengan pembuatan sistem informasi gudang dalam ketersediaan stok barang dengan metode buffer stok berbasis web

\section{Metode Analisis Kebutuhan Fungsional}

Analisis kebutuhan fungsional dilakukan untuk mengetahui proses-proses apa saja yang dilakukan oleh sistem (Darwis, Pasaribu and Surahman, 2019). Berikut ini merupakan fungsionatias apa saja yang dibutuhkan oleh sistem informasi inventory gudang dalam ketersediaan stok barang menggunakan metode buffer stock

1. Sistem harus dapat melakukan pengolahan data master yaitu melakukan pengolahan data kategori, data satuan, data satuan, data bahan, data nama barang, data warna dan data ukuran

2. Sistem harus dapat melakukan pengolahan data barang

a. Admin dapat memasukkan data-data barang

b. Admin dapat mencari data barang

c. Admin dapat menampilkan data barang

d. Admin dapat menyimpan, mengubah, menghapus data barang.

3. Sistem harus dapat melakukan pengolahan data pemesanan

a. Admin dapat memasukkan data pemesanan

b. Admin dapat menyimpan, mengubah, menghapus data pemesanan

c. Admin dapat menampilkan data pemesanan 
4. $\quad$ Sistem harus dapat melakukan pengolahan data buffer stock

a. Admin dan pimpinan dapat mengetahui jumlah buffer stock perbulan

b. Admin dan pimpinan dapat mencetak buffer stock

5. Sistem harus dapat melakukan pengolahan data retur

a. Admin dapat melakukan penginputan retur

b. Admin dapat mengubah data retur

c. Admin dapat menghapus data retur

d. Admin dapat menampilkan data retur berdasarkan pencarian.

6. Sistem harus dapat melakukan pengolahan data laporan

a. Admin dan pimpinan dapat mencetak laporan persediaan barang

b. Admin dan pimpinan dapat mencetak laporan pemesanan

c. Admin dan pimpinan dapat mencetak laporan buffer stock.

\section{HASIL DAN PEMBAHASAN}

\section{Use Case Diagram}

Use case atau diagram use case merupakan pemodelan untuk kelakuan (behavior) sistem promosi yang akan dibuat. Use case merupakan konstruksi untuk mendeskripsikan bagaimana sistem akan terlihat di mata user, sedangkan use case diagram memfasilitasi komunikasi diantara analis dan pengguna serta antara analis dan client (Rosa, 2016). Berikut adalah use case diagram yang dapat dilihat pada gambar 2 dibawah ini :

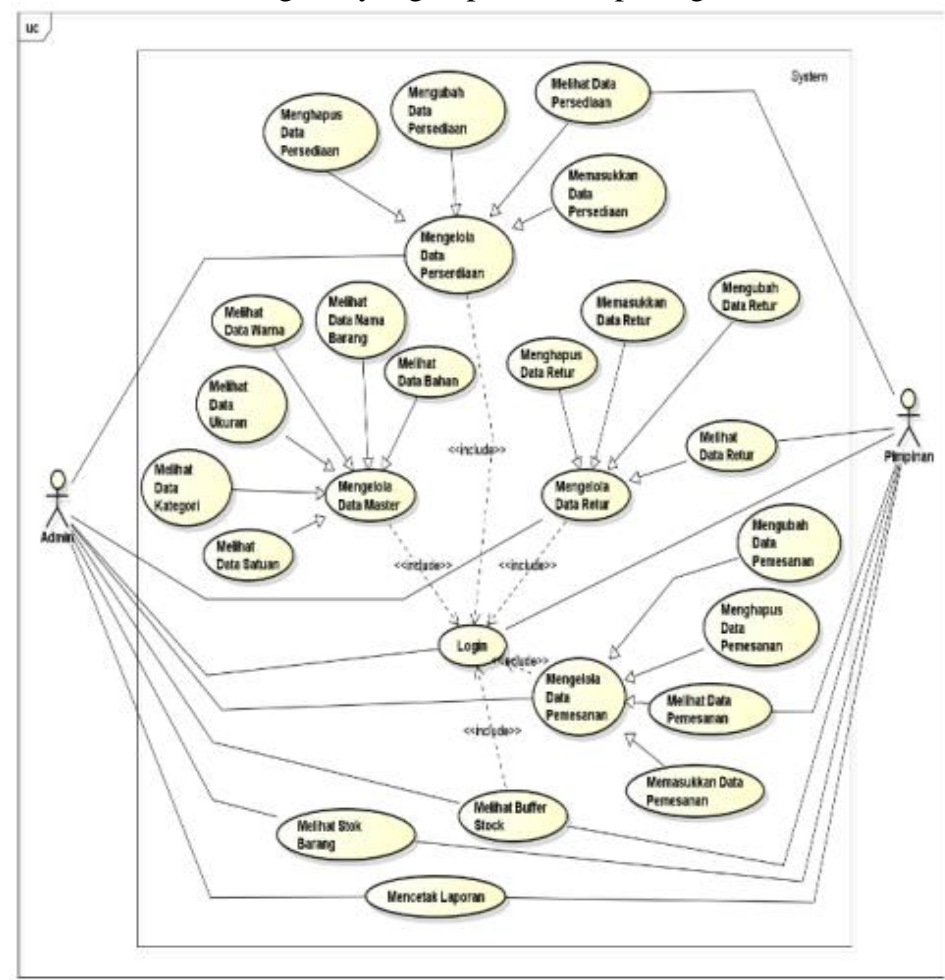

Gambar 2 Usecase Diagram

\section{Implementasi Sistem}

Setelah melakukan proses analisa, perancangan dan pembuatan aplikasi yang sudah jadi akan diimplemetasikan pada Rika 86 untuk menguji layak atau tidaknya sistem. Selain dengan implementasi langsung terdapat juga pengujian black box. Kemudian melakukan pelatihan terhadap admin maupun pimpinan yang akan menggunakan aplikasi dan pengetahuan yang cukup tentang penggunaan aplikasi yang dibuat, agar admin dan pimpinan dapat 
memahami cara pengggunaan aplikasi tersebut (Eka, Putri and Surahman, 2020), serta dapat mengurangi kesalahan yang akan timbul, sehingga tujuan perancangan sistem dalam memberikan informasi persediaan bahan pada Konveksi Rika 86 Lampung dapat tercapai.

\section{Tampilan Halaman Login}

Halaman Login digunakan untuk masuk ke menu dashboard sistem, login dapat dilakukan oleh admin dan pimpinan. Jika menginputkan username dan password dengan benar maka sistem akan menampilkan halaman dashboard jika tidak maka akan memberikan pesan gagal login. Halaman login dapat dilihat pada gambar 3

\section{Tampilan Halaman Dashboard}

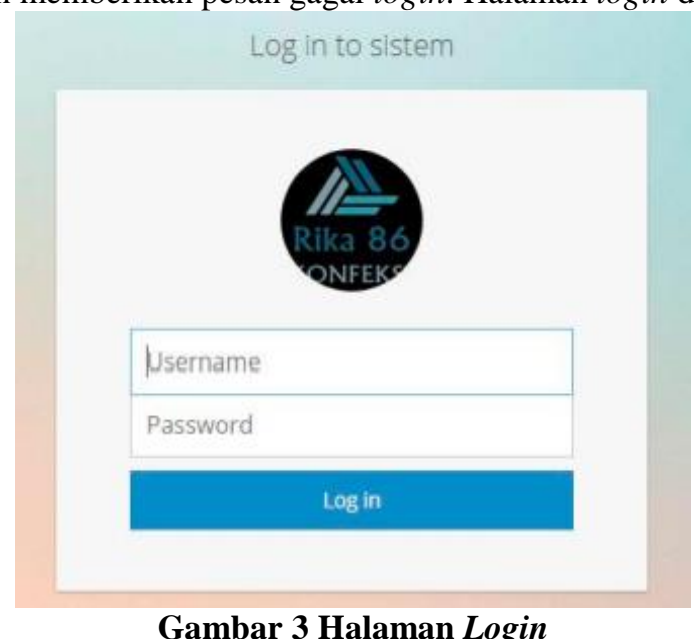

Implementasi Menu Utama Admin berisi menu-menu pilihan yang berkaitan dengan seluruh aplikasi penggunaan program. Terdapat beberapa menu pada menu utama admin seperti menu master untuk menginputkan data kategori, data satuan, data bahan, data nama bahan, data warna dan data ukuran, kemudian ada menu persediaan bahan, pemesanan, buffer stock, retur dan user. Tampilan rancangan menu utama dapat dilihat pada gambar 4 .

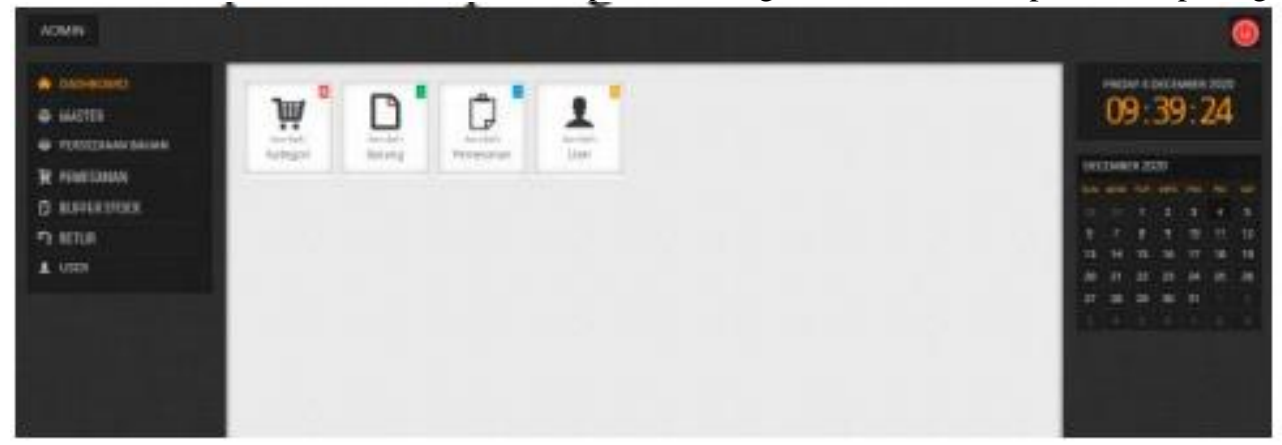

\section{Gambar 4 Halaman Dashboard}

\section{Implementasi Halaman Data Persediaan Bahan}

Halaman ini digunakan untuk

digunakan untuk melihat data bahan yang sudah diinputkan. Tampilan rancangan form menu data persediaan bahan dapat dilihat pada gambar 5 . 


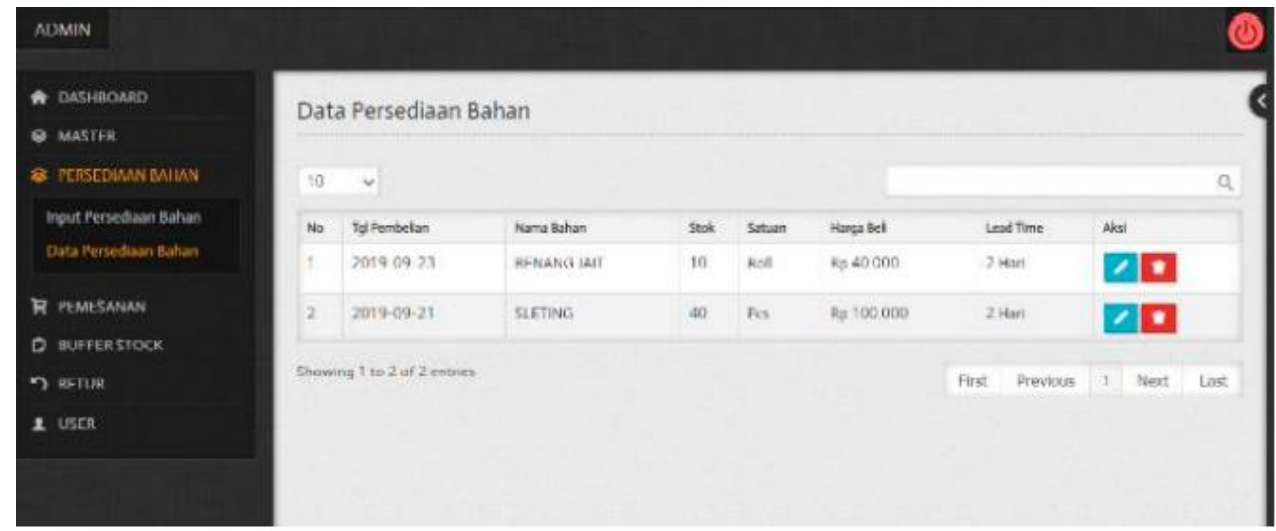

\section{Gambar 5 Halaman Data Persediaan}

\section{Implementasi Halaman Input Persediaan Bahan}

Halaman ini digunakan untuk menginputkan data persediaan bahan, tombol simpan digunakan untuk menyimpan data, dan tombol bersih untuk membersihkan form. Tampilan rancangan halaman input data persediaan bahan dapat dilihat pada gambar 6.

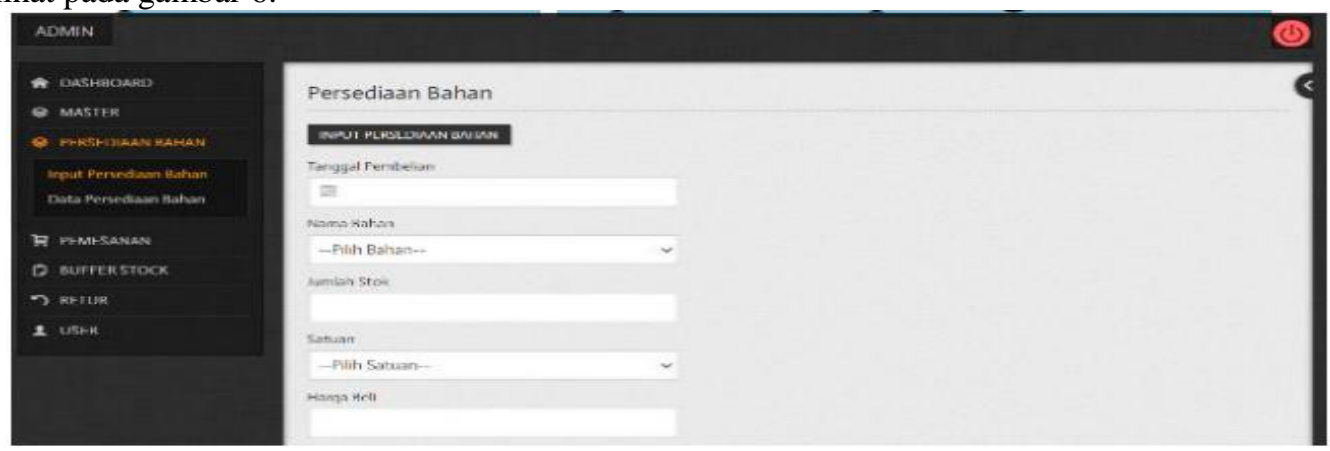

\section{Implementasi Halaman Data Buffer Stock}

\section{Gambar 6 Halaman Input Data Persediaan}

Halaman ini digunakan untuk melihat perhitungan bahan berdasarkan metode buffer stock. Tombol lihat perhitungan buffer stok digunakan untuk melihat perhitungan persediaan bahan perbulan yang sudah dipilih. Tampilan rancangan form menu data buffer stock dapat dilihat pada gambar 7 dan gambar 8 .

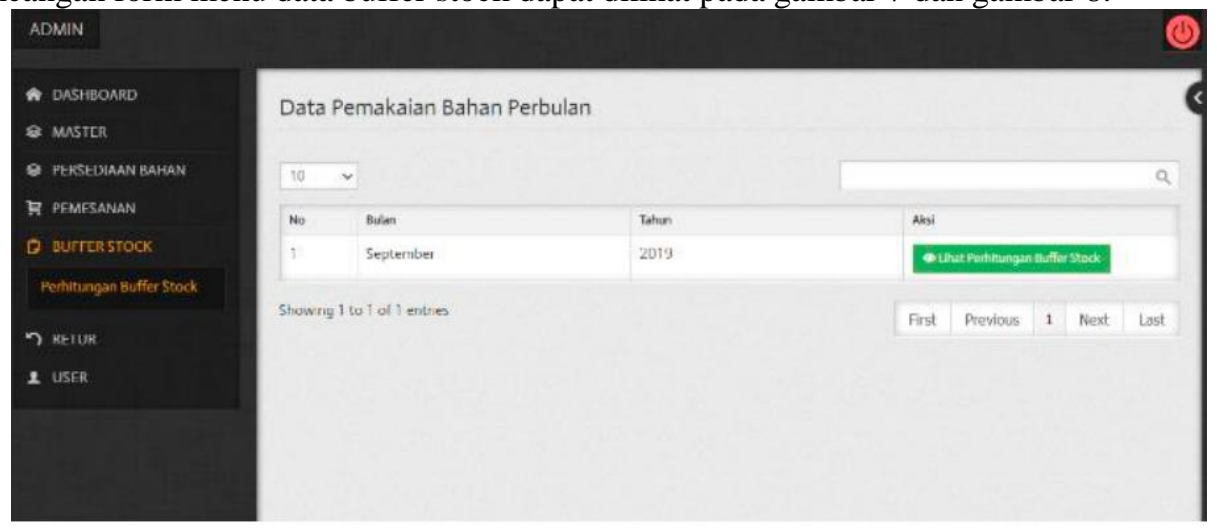

Gambar 7 Halaman Data Buffer Stock 


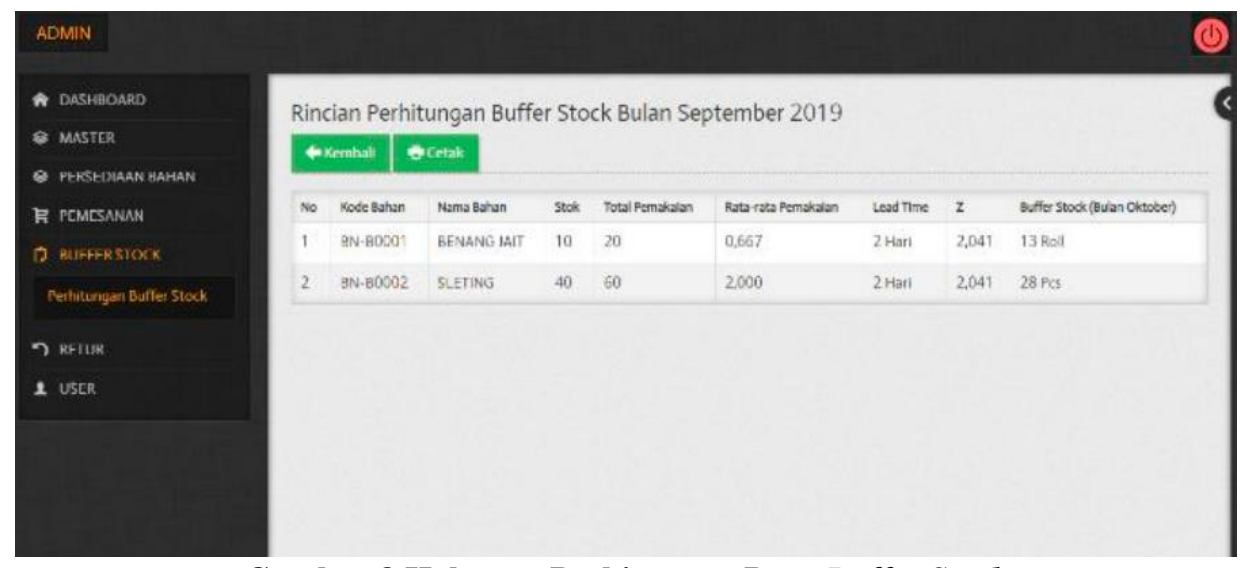

Gambar 8 Halaman Perhitungan Data Buffer Stock

\section{Perhitungan Buffer Stock}

Pemakaian perbulan september 2019 atau total 30 hari memiliki jumlah pemakaian sebanyak 20

1. Untuk lead time sudah ditentukan oleh perusahaan yaitu 2 hari

2. Untuk mendapatkan service level didapat dari 100 dikurang dengan lead time yaitu 2 hasilnya adalah 98

3. Kemudian lead time 2 dibagi dengan 98 hasilnya adalah 0,021

4. Kemudian 0.021 dikalikan dengan 100 hasilnya adalah 2,041

5. Service level atau nilai $\mathrm{Z}$ yang didapat yaitu 2,041

6. Rata pemakaian $=$ jumlah pemakaian dibagi 30 hari

7. Rata pemakaian $=20$ dibagi 30

8. $\quad$ Rata pemakaian $=0,666$

9. Hasil Buffer Stock $=$ Jumlah Pemakaian $+($ service level $\mathrm{x}$ rata-rata pemakaian $\mathrm{x}$ lead time $)-$ sisa stok

10. Hasil Buffer Stock $=20+(2,041 \times 0,667 \times 2)-10$

11. Hasil Buffer Stock untuk benang jait = 12,72 jika dibulatkan menjadi 13 .

\section{Pengujian Black Box}

Blackbox (blackbox testing) adalah salah satu metode pengujian perangkat lunak yang berfokus pada sisi fungsionalitas, khususnya pada input dan output aplikasi (apakah sudah sesuai dengan apa yang diharapkan atau belum) (Pressman, 2010). Tahap pengujian atau testing merupakan salah satu tahap yang harus ada dalam sebuah siklus pengembangan perangkat lunak (selain tahap tampilan atau desain). hasil uji kelayakan sistem yang sudah dilakukan oleh 2 orang pengguna sistem yaitu: admin dan pimpinan. Data pada penelitian ini diperoleh dari hasil pengisian berupa pengujian blackbox yang berjumlah 29 pertanyaan dan diberikan kepada responden untuk menilai hasil kelayakan dari perangkat lunak yang dirancang

1. Hasil Pengujian Admin

Hasil = (jumlah diterima / jumlah pertanyaan) $\mathrm{x} 100 \%$

$$
=(31 / 31) \times 100 \%
$$

$$
=100 \%
$$

2. Hasil Pengujian Pimpinan

Hasil = (jumlah diterima / jumlah pertanyaan) $\times 100 \%$

$$
=(31 / 31) \times 100 \%
$$

$$
=100 \%
$$

3. Total Pengujian $=($ Hasil pengujian $/$ jumlah responden $)$

$$
\begin{aligned}
& =(100+100) / 2 \\
& =100 \%
\end{aligned}
$$


Berdasarkan hasil uji kelayakan sistem yang telah dilakukan, pengujian ini menggunakan 2 (dua) responden dengan kesimpulan bahwa kualitas perangkat lunak yang dihasilkan memiliki tingkat yang Sangat Layak.

\section{SIMPULAN}

Berdasarkan pembahasan sistem informasi inventory gudang dalam ketersediaan stok barang menggunakan metode buffer stock berbasis web dapat diambil kesimpulan yaitu Hasil yang didapat adalah proses persediaan barang dengan metode Buffer Stock dapat membantu Konveksi Rika 86 Lampung untuk mengetahui jumlah persediaan barang atau bahan yang ada dan dapat mengetahui jumlah persediaan yang harus di pesan berdasarkan perhitungan Buffer Stock.

\section{UCAPAN TERIMA KASIH}

Puji syukur penulis panjatkan kepada Allah SWT, karena atas berkat dan rahrnat-Nya, penulis dapat menyelesaikan penelitian dengan judul "Sistem Informasi Inventory Gudang Dalam Ketersediaan Stok Barang Menggunakan Metode Buffer Stok".

1. Bapak Dr. H.M. Nasrullah Yusuf, S.E., M.B.A. selaku Rektor Universitas Teknokrat Indonesia.

2. Bapak Dr. H. Mahathir Muhammad, S.E., M.M. selaku Dekan Fakultas Teknik dan Ilmu Komputer Universitas Teknokrat Indonesia.

3. Ibu Dyah Ayu Megawaty, M.Kom., selaku Ketua Program Studi S1 Informatika Fakultas Teknik dan Ilmu Komputer Universitas Teknokrat Indonesia.

\section{REFERENSI/DAFTAR PUSTAKA}

Darwis, D., Pasaribu, A. F. and Surahman, A. (2019) 'Sistem Pencarian Lokasi Bengkel Mobil Resmi Menggunakan Teknik Pengolahan Suara dan Pemrosesan Bahasa Alami', Jurnal Teknoinfo, 13(2), pp. 71-77.

Eka, S., Putri, Y. and Surahman, A. (2020) 'PENERAPAN MODEL NAIVE BAYES UNTUK MEMPREDIKSI POTENSI PENDAFTARAN SISWA DI SMK TAMAN SISWA TELUK', 1(1), pp. 81-86.

Maulida, S., Hamidy, F. and Wahyudi, A. D. (2020) 'Monitoring Aplikasi Menggunakan Dashboard Untuk Sistem Informasi Akuntansi Pembelian Dan Penjualan', Jurnal TEKNO KOMPAK, 14(1), pp. 47-53.

Megawaty, D. A. et al. (2020) 'SISTEM MONITORING KEGIATAN AKADEMIK SISWA', 14(2), pp. 98-101.

Nawang, M., Kurniawati, L. and Duta, D. (2017) 'Rancang Bangun Sistem Informasi Pengolahan Data Persediaan Barang Berbasis Dekstop Dengan Model Waterfall', Jurnal Pilar Nusa Mandiri, 13(2), pp. 233-238.

Pressman, R. (2010) Software Quality Engineering: A Practitioner's Approach, Software Quality Engineering: A Practitioner's Approach. doi: 10.1002/9781118830208.

Rosa, A.S. and Shalahuddin, M. (2016). Rekayasa Perangkat Lunak Terstruktur dan Berorientasi Objek. Bandung: Informatika Bandung.

Setiawansyah, Sulistiani, H. and Darwis, D. (2020) 'Penerapan Metode Agile untuk Pengembangan Online Analytical Processing ( OLAP) pada Data Penjualan ( Studi Kasus : CV Adilia Lestari )', Jurnal CoreIT, 6(1), pp. 50-56.

Sulistiani, H. et al. (2020) 'Pemanfaatan Analisis Biaya Dan Manfaat Dalam Perhitungan Kelayakan Investasi Teknologi Informasi', Jurnal Ilmiah Edutic, 6(2). doi: https://doi.org/10.21107/edutic.v6i2.7220.

Wulandari, Y. and Sulistiani, H. (2020) 'RANCANG BANGUN APLIKASI PRESENSI SMS GATEWAY BERBASIS WEB DENGAN FRAMEWORK CODEIGNITER PADA', 1(1), pp. 43-50. 